\title{
SOIL EROSION ASSESSMENT IN WOOD PASTURES \\ AND TREE-LESS PASTURES \\ (A CASE STUDY: HÂRTIBACIULUI TABLELAND)
}

\author{
Cristina-Alina FICUȚ ${ }^{1}$, Vlad MĂCICĂȘAN ${ }^{1}$, Cristian-Valeriu \\ MALOȘ $^{1}$, Octavian-Liviu MUNTEAN ${ }^{1}$, Gheorghe ROŞIAN ${ }^{1}$, \\ Tibor HARTEL ${ }^{2}$
}

Keywords: soil erosion, pastures, GIS, RUSLE, old trees

\begin{abstract}
The management of pastures is very important to reduce soil erosion. A special attention is generally needed for the wood pastures which combine livestock grazing with trees and shrubs. In this paper, we investigated the differencess between the wood pastures and tree-less pastures and their role to prevent or mitigate the soil erosion. The soil erosion assessment has been performed by using of RUSLE and GIS. The model has been applied in two study-polygons with wood pasture and tree-less pasture located in the northern part of Hartibaciului Tableland (Romania). Our outcomes showed and highlighted by comparison that wood pastures have a lower predicted annual soil loss than pastures with accidental presence of trees. This fact suggests that wood pastures are more resilient to soil erosion than tree-less pasture. The metholology tried to calibrate a preliminary model of soil erosion assessment for wood pastures into the southern part of Transylvania.
\end{abstract}

\section{Introduction}

In many pastures and wood pastures, soil erosion is an extensive dual process generated by a mix of natural and anthropogenic factors such as topography and steep slopes, geomorphological processes, overgrazing, fire, inappropriate farming practices, livestock types and so on. As a consequence,

\footnotetext{
${ }^{1}$ Faculty of Environmental Science and Engineering, Bab-Bolyai University, 30 Fântânele Str., 400294, Cluj-Napoca, Romania.

${ }^{2}$ Ecosystem Service laboratory, Faculty of Sciences and Arts, Sapientia Hungarian University of Transilvania, 4 Calea Turzii, 400193, Cluj-Napoca, Romania.
} 
soil erosion can be a serious problem on pastures with or without trees or shrubs.

Pastures are an important resource for feeding livestock and have an outstanding value for biodiversity. In many cases, wood pastures can better control soil erosion than the pastures without trees.

Generally, pastures are defined as natural or artificial grasslands used for grazing livestock. Wooded-pastures include those pastures that apart from grassy vegetation are also covered with forest vegetation with varying degrees of consistency. There are also pastures with shrubs and clean pastures which are grasslands covered only with grassy vegetation.

Wooded pastures are found in many European countries, though some are without old trees. Today there is an increasing interest in the restoration and continuation of wood pasture sites. Currently there are several local initiatives which aim to conserve and emphasize the economic potential of the rich cultural and ecological heritage of these high nature value landscapes (Hartel et al., 2016).

The impact of geomorphological processes on landforms with pastures is high, especially in the northern part of Hârtibaciu Tableland. The erosional processes are represented here by very active torrents, gullies and shallow landslides which contribute to the degradation of terrains, fragility of ecosystems and vulnerability of ecological services.

\section{STUDY AREA}

The study area is located in Mureș County (Figure. 1), in the geomorphological unit of Roandola Hills, which is an integral part of the northern Hârtbaciului Tableland. The elevation values are not exceeding $700 \mathrm{~m}$ in the eastern part of the unit but decreases to $600 \mathrm{~m}$ and less in the western part.

An important feature is the presence of a high level of terrain fragmentation due to the numerous small valleys that drain towards Târnava Mare and Hârtibaciu rivers. Roandola Hills are limited by Târnava Mare Corridor on the north, Șaeș Valley on the east, Hârtibaciu Valley on south, and Valea Moşnei on the west (Pop, 2001).

The litology of the area is dominated by Pannonian deposits, which are low differentiated sedimentation strata (Gârbacea and Grecu, 1984). The pannonian sedimentary formations represent an alternation of impermeable marly-clay strata and permeable strata of sands, loosely cemented sandstones and conglomerates with a monocline structure, locally disturbed by folds of a general E-W or N-S orientation (Grecu and Sandu, 1999). 
In the proximity of studied polygons, a specific morphological issue is generated by the presence of some "micro-canions" as a result of the torrential and gully erosion on very steep slopes (Muntean, 2004). Even if the vecinity area of pastures is wooded, the intensity of these geomorphological processes is very high and can lead to the rapid fragmentation of these areas.

The overall morphology is the result of the geological substrate modeling by the hydrographic network, which, through erosion and valley formation, left behind two types of morphological surfaces:

(a) quasi-horizontal surfaces such as leveling surfaces;

(b) inclined surfaces of the type of the slopes.

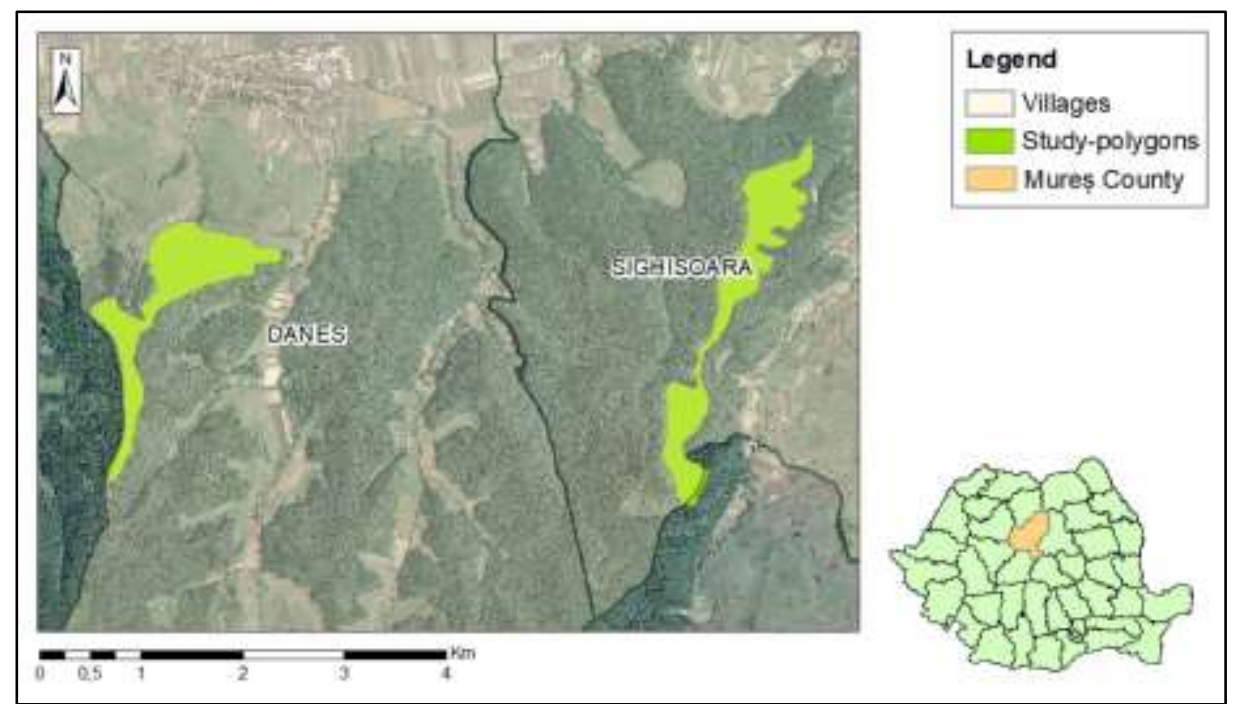

Figure 1. Geographical location of the study area and polygons

The specific alternation of the two types of surfaces is the basis for the delimitation and differentiation of Roandola Hills relative to the surrounding morphological units (Roşian, 2011).

The soils show a high eterogenity, varring from luvisols to hidrisols and more acid or lime-poor soils over the sands; the clays are at the base of more dry soils, and the thin-bedded limestone generate base-shallow soils resembling rendzina and erodosol (Akeroyd and Page, 2006; Muntean, 2004).

In the northern part of Hârtibaciului Tableland, the arable land occupies about $15 \%$ of the land, the pastures and meadows reaching $40 \%$, and the forests about $30 \%$. 
This area is characterized by mixed oak (Quercus petraea) and hornbeam (Carpinus betulus) forests, found on hills and plains on southern slopes, and mixed beech (Fagus sylvatica) and hornbeam, predominant on northern slopes (Ficuț et al., 2017).

\section{MATERIAL AND METHOD}

For the soil erosion assessment, we selected and delimited two studypolygons (Figure 1). The two study-polygons are represented by two typical and, also, different pastures located on the similar morphological leveling surfaces (Figure 2):

(a) A wood pasture with old trees (scattered oaks such as Quercus robur and Q. petraea) in a variable density between cca 3-10 trees ha-1; this area is the subject of conservation management (Breite Plateau with Ancient Oak Trees Nature Reserve, located near Sighişoara town);

(b) A tree - less pasture with accidental presence of woody vegetation

dominated by pear (Pyrus communis and P. pyraster) with a nonconservation management (Şeştini Plateau, located near Daneș village).

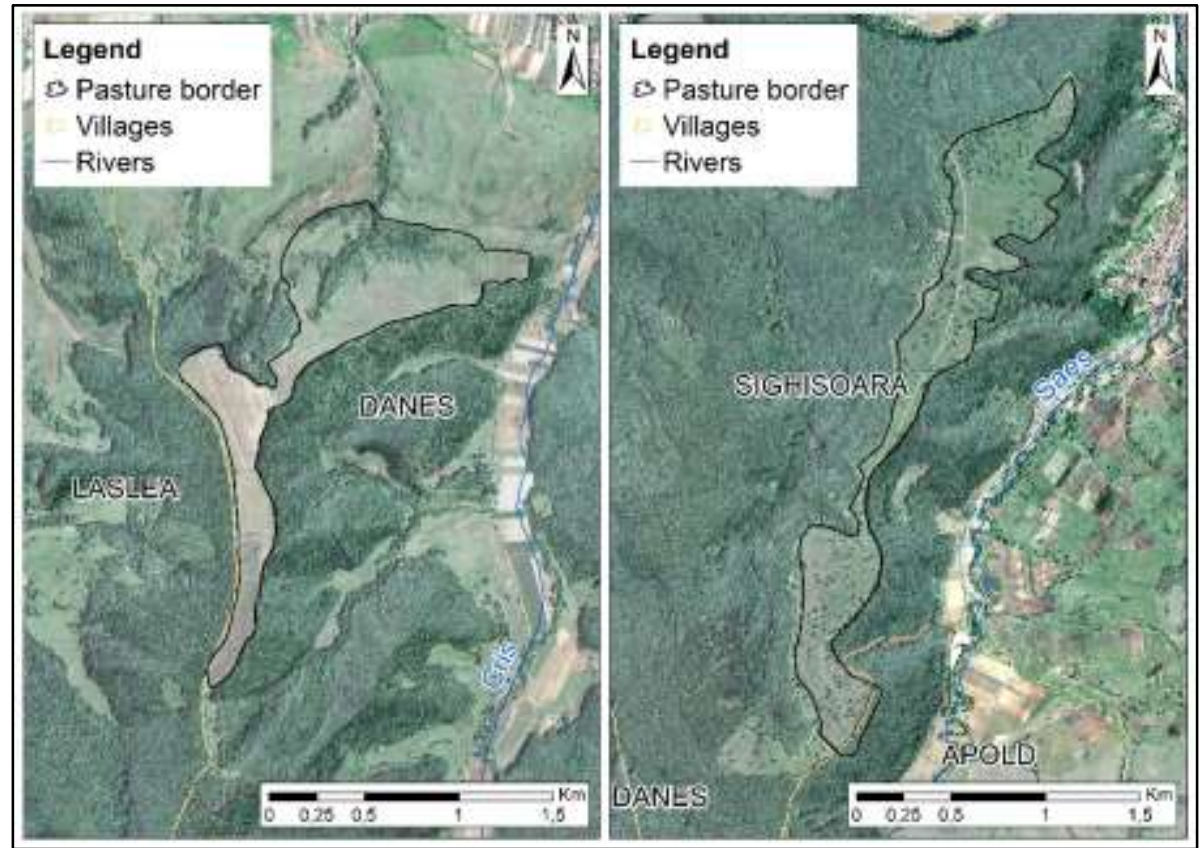

Figure 2. The location, morphology and borders of studied pastures 
Each polygon had approximately $1 \mathrm{~km}^{2}$ area (Table 1) and they were selected in order to calibrate a similar model and methodology developed and used by us in the same geographical unit (Ficut et al., 2017).

Each pasture polygon was comprehensively surveyed in the field for trees, grass and shrubs. We analyzed and determined the size (trunk circumference, height, crown diameter) as well as the species of the trees and also located the trees with handheld GPS. An identification of main habitats of studied area was also realized in order to establish their territorial connections.

The tree-less pasture is composed of mountain hay meadows (habitat 6520 in the Natura 2000 classification) and semi-natural dry grassland and scubland (habitat 6210). The semi-natural grassland habitat is usually found in areas where carbonaceous clays and marls are present, on slopes facing south.

Mountain hay meadows are found usually in the higher mountain areas. Here the habitat is related to the little excesive water balance in some areas where clays are near the surface and also to the lower average temperatures.

The Breite plateau is classified as a forest fringe habitat, being differentiated from grassland by the presence of tree species.

The oak wood pasture from Breite Plateau Nature Reserve - Sighișoara (74 ha) contained over 300 old trees (predominantly mature oak) which were considered 'large old' (Hartel et al., 2018), while none of such trees were not found in Şeştini Plateau - Daneș (tree-less pasture).

We were able to identify this pasture areal with complete absence of trees near Daneş village and to a distance of about $6.5 \mathrm{~km}$ from Breite Plateau Natural Protected Area (near Sighişoara town). Breite Plateau Natural Protected Area is a typical wooded-pasture with sparse woody vegetation that had partially benefited by a conservative status into the last decades.

In order to test and calibrate a model of the relationship between trees and soil erosion, we used as an important parameter the crown diameter for each tree identified on site (Ficuț et al., 2017).

In many pastures, the crowns of trees are functioning as buffer elements which protect the surface of soils from denudation. Therefore, we were able to calculate the total area covered by the tree crowns, in the investigated pastures (1).

\subsection{RUSLE model and GIS-based assessment}

The methodology applied for soil erosion assessment was based on the implementation of the RUSLE (Revised Universal Soil Loss Equation) in a GIS environment.

Until recently one of the most widely applied empirical models for assessing erosion was the Universal Soil Loss Equation (USLE), developed by 
Wischmeier and Smith in 1965 (Ferencik et al., 2008). However, since then RUSLE has been adopted as the standard tool for erosion prediction on various degraded lands.

The RUSLE (Revised Universal Soil Loss Equation) model represents a set of mathematical equations that estimate the average annual soil loss and accumulation of sediment resulting from surface erosion (Toy and Foster, 1998; Foster et al., 2003).

One of the great benefits of the RUSLE model used in this study is that it allows the presentation of the results in both graphical and cartographic form. This model is based on the formula developed by Wischmeier and Smith (1965), which are presented as follows:

$$
A=R \cdot K \cdot L s \cdot C \cdot P
$$

Where,

$\mathrm{A}=$ Average annual soil loss (in tons per hectares per year);

$\mathrm{R}=$ Rainfall/runoff erodibility

$\mathrm{K}=$ Soil erodibility

Ls $=$ Hillslope length and steepness

$\mathrm{C}=$ Land Cover-management

$\mathrm{P}=$ Support practice

The $\mathrm{R}$ factor is an expression of the erosivity of rainfall and runoff at a particular location. This coefficient was extracted from the map of Romania's pluvial aggressiveness (Moțoc and Sevastel, 2002), according to which the study area belongs to the area no. 7, which exhibits a rainfall aggression coefficient $(\mathrm{R})$ of 0.12 .

The $\mathrm{K}$ factor is an expression of the inherent erodibility of the soil or surface material at a particular site under standard experimental condition (Toy and Foster, 1998). The coefficients of soil erodibility are dependent on soil type and texture. These coefficients have been extracted from Moțoc et al. (1975) and vary in our case between 0.8 and 1.1.

The Ls factor is an expression of the effect of topography, more specifically the hillslope length and steepness (Toy and Foster, 1998). In the present paper, in order to determinate the Ls factor, a digital elevation model with a resolution of $5 \mathrm{~m}$ was used, which was interpreted using GIS techniques, the result being then introduced into the formula (GIS function) developed by Mitasova et al. (1996).

The $\mathrm{C}$ factor is an expression of the effect of surface covers and roughness, soil biomass, and soil-disturbing activities on rate of soil loss at a 
particular site (Toy and Foster, 1998). In order to obtain this coefficient, a first step was to develop a detailed map by digitizing every land use polygon from the orthophotomaps, using the ArcGIS software, at a spatial resolution of $5 \mathrm{~m}$. The polygons were also verified in the field and modified accordingly. The next step was to extract the values corresponding to the specific coefficients of each land use type, from the national database developed by Moțoc and Sevastel (2002). In our case, this coefficient varies between 0.001 and 0.8 .

The $\mathrm{P}$ factor is an expression of the effects of supporting conservation practices such as contouring, buffer strips of close-growing vegetation, and terracing, on soil loss at a particular site (Toy and Foster, 1998).

For Romania, the values corresponding to different methods and measures of soil erosion mitigation were determined by Moțoc and Sevastel (2002). Accordingly, the value of 0.1 was assigned for this factor, which corresponds to the absence of soil control and mitigation measures.

As a rule, the values of erosion are influenced by geology, soil type, slope declivity, and land cover management. When these four determining factors are setting into a model is it easy to estimate the mathematical value of soil erosion (Ferencik et al., 2008). These factors have been obtained using ArcGIS software, by applying a specific layer for each factor and then applying the RUSLE formula (1).

\section{RESULTS AND DISCUSSIONS}

The RUSLE model has been applied in the two-above-mentioned studypolygons. The results, both numerical and cartographic (Figure 3), suggest that the soil loss rate in the polygon corresponding to the wood pasture (SighișoaraBreite Plateau) was much lower than the rate of soil loss in the polygon corresponding to the tree-less pasture (Daneș-Șeștini Plateau).

This fact totally confirms the preliminary results obtained in a previous study realized on the eastern part of the analized geographical unit (Ficut et al., 2017).

The higher values for the wood pasture area in Figure 3 are actually recorded outside the actual wood pasture area, in a buffer zone we used for the calibration of the model. There are some active ravines and torrents in the immediate vicinity of the study are and we wanted to check if the higher erosion rate will come up in the model.

The maximum value of the average annual soil loss for the polygon of wood pastures was lower than the maximum value of the same parameter for the polygon of

tree-less pastures (Figure 4). 
The values for average annual soil loss calculated for the two sites show that there is a higher soil loss rate in the case of Daneș-Șeștini (tree-less pasture). Here, the

value of maximum annual soil loss rate is $0.4242 \mathrm{t} / \mathrm{ha} / \mathrm{yr}$ compared to the value of $0.0243 \mathrm{t} / \mathrm{ha} / \mathrm{yr}$ in Sighișoara-Breite wood pasture.

In terms of average values, the differences are also relatively high. There is an average of $0.0063 \mathrm{t} / \mathrm{ha} / \mathrm{yr}$ soil loss for the Daneș-Șeștini pasture, as compared to only $0.00061 \mathrm{t} / \mathrm{ha} / \mathrm{yr}$ soil loss for the Breite area.

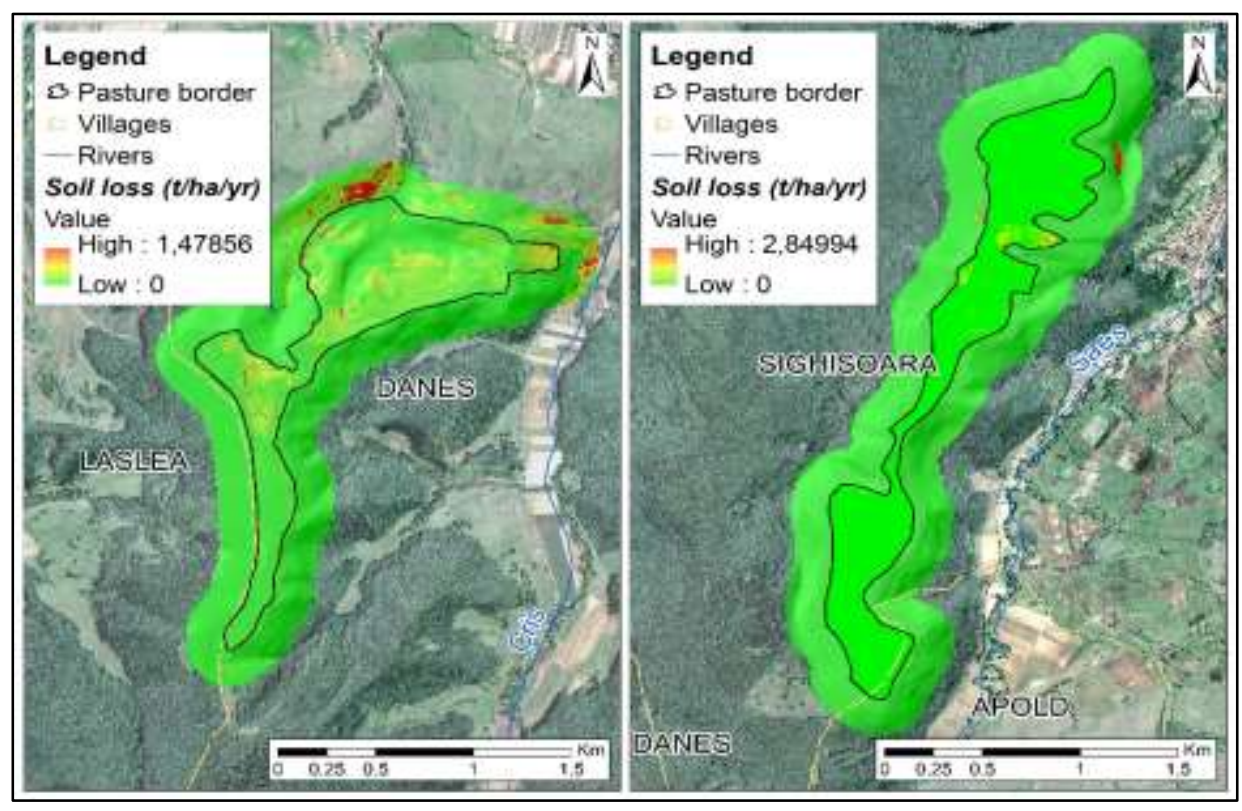

Figure 3. Soil erosion maps of Breite and Șeștini plateaus (surfaces with surrounding area-buffer of $200 \mathrm{~m}$ )

Table 1 and Figure 5 show these values compared to the values determined in a previous study (Ficuț et al., 2017), focusing on other 4 wood pasture and pasture areas from the same region.

The soil loss rate is clearly higher for pastures without trees, as wood pastures have lower soil loss rates. The variation of the soil loss rate in the case of wood pastures is also determined by the intensity of grazing and other traditional agricultural practices.

The values for average annual soil loss calculated for the two sites show that there is a higher soil loss rate in the case of Daneș-Șeștini (tree-less 
pasture). Here, the value of maximum annual soil loss rate is 0.4242 $\mathrm{t} / \mathrm{ha} / \mathrm{yr}$ compared to the value of $0.0243 \mathrm{t} / \mathrm{ha} / \mathrm{yr}$ in Sighișoara-Breite wood pasture.

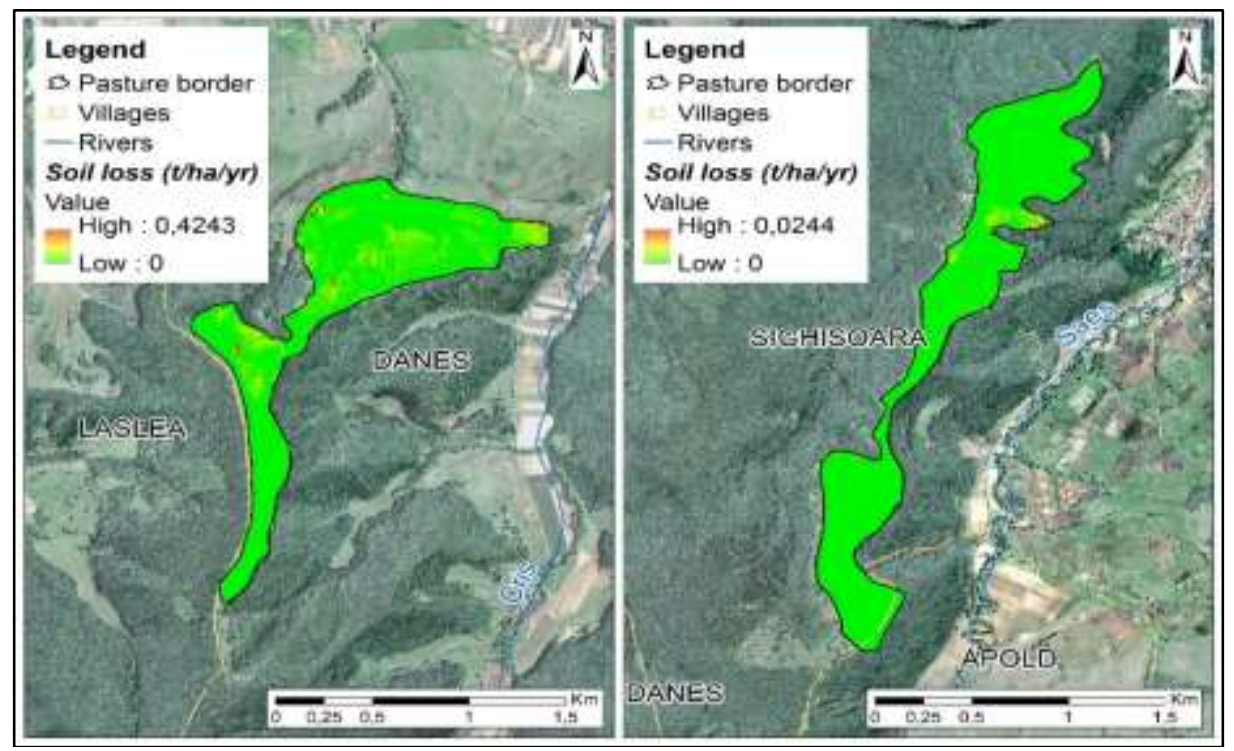

Figure 4. Soil erosion maps of Breite and Șeștini plateaus (surfaces of pastures only)

In terms of average values, the differences are also relatively high. There is an average of $0.0063 \mathrm{t} / \mathrm{ha} / \mathrm{yr}$ soil loss for the Daneș-Şeștini pasture, as compared to only $0.00061 \mathrm{t} / \mathrm{ha} / \mathrm{yr}$ soil loss for the Breite area.

Table 1 and Figure 5 show these values compared to the values determined in a previous study (Ficuț et al., 2017), focusing on other 4 wood pasture and pasture areas from the same region.

The soil loss rate is clearly higher for pastures without trees, as wood pastures have lower soil loss rates.

The variation of the soil loss rate in the case of wood pastures is also determined by the intensity of grazing and other traditional agricultural practices.

Table 1. The difference between the total area of pastures and the area occupied by tree crowns (adapted and completed after Ficuț et al., 2017) 
58 Cristina-Alina Ficuț, V. Măcicăşan, C-V. Maloș, O-L. Muntean, G. Roşian, T. Hartel

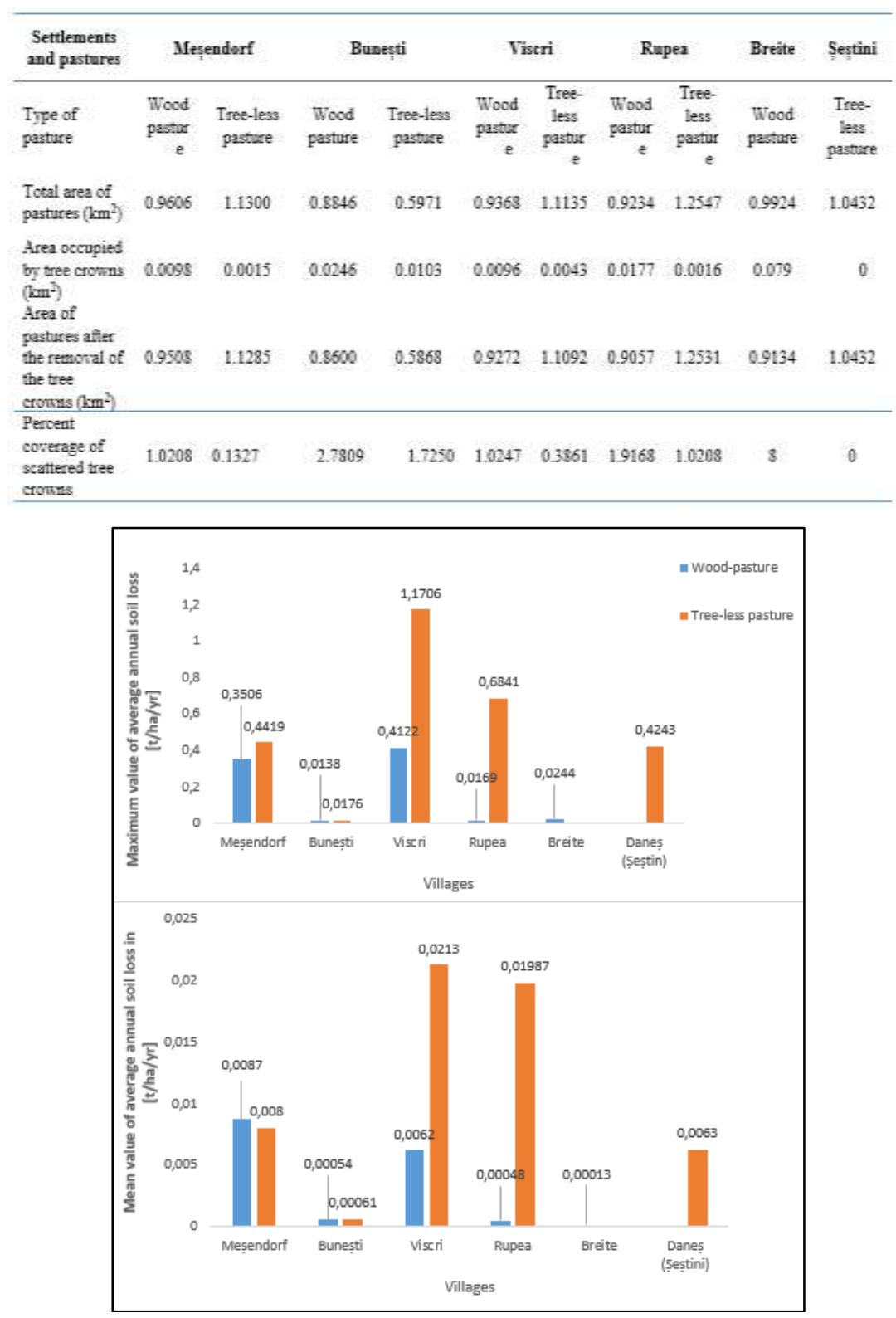

Figure 5. The maximum and mean values of annual soil loss in wood pastures and tree-less pastures (adapted and completed after Ficuț et al., 2017) 


\section{Conclusions}

In this paper we investigate the potential of wood pastures to provide regulating ecosystem services by their ability to prevent or mitigate the soil erosion. In order to compare outcomes of the similar studies (based on RUSLE and GIS), a calibrating model of soil erosion for wood pastures and tree-less pastures from Hârtibaciu Tableland was analyzed and discussed.

Interfluvial surfaces (leveling morphological surfaces) and steeped slopes are the main features of the geomorphological landscape in the northern side of Hârtibaciului Tableland which is also reflected in land use planning (Șeștini Plateau-Daneș) and nature conservation management (Breite PlateauSighișoara).

Within the surface of analyzed pastures, the main problem remains land degradation, which if not treated continues to intensify and extend. The main consequences include the landscape degradation, fragmentation of habitats, soil fertility decline, and loss of ecosystems services.

On the basis of RUSLE assessment, we concluded that lower rates of soil erosion coincided with substantial amount of wood pasture coverage (Breite Plateau - Sighișoara) while the polygon representing pastures without trees had relatively higher soil erosion rates (Șeștini Plateau-Daneș).

On a hand, local geodiversity (leveling morphological surfaces) and nature conservation measures were favorable to maintaining of biodiversity and resilience of wood pastures in this geographical area.

On the other hand, wood pastures have been contributed to the regulation of soil erosion on the quasi-horizontal surfaces analyzed. In addition, the process of slopes fragmentation by torrential erosion in the proximity of the analyzed areas is also diminished by the presence of wooded pastures.

As a final conclusion, we consider this soil erosion assessment, based on RUSLE model and GIS, is a useful tool for the conservation planning of wooded pastures and tree-less pastures.

\section{References}

Akeroyd J.R., Page, N., 2006, The Saxon Villages of Southern Transylvania: Conserving Biodiversity in a Historic Landscape, In: Gafta D., J. Akeroyd, (Eds), Nature Conservation. Environmental Science and Engineering. Springer, Berlin, Heidelberg, 199-210.

Ferencik, I., Muntean, O.-L., Mihăiescu, R., Dimen, L., 2008, Assessment of Soil Erosion Using Usle and GIS (Case Study: Vărzari Coal Quarry, Romania), RevCAD, Journal of Geodesy and Cadastre, no. 8, Alba Iulia, pp. 247-256. 
Ficuț, Cristina Alina, Muntean, O.-L., Măcicăşan, V., Maloş, C.-V., Hartel, T., 2017, A GIS-based Assessment of Soil Erosion in Wood pastures of Southern Transylvania, BIOFLUX, ProEnvironment 10, pp. 62-70.

Foster, G.R., T.J. Toy, K.G. Renard, 2003, Comparison of the USLE, RUSLE1.06c and RUSLE2 for Application to Highly Disturbed Lands, Proceedings of the First Interagency Conference on Research in the Watersheds, Benson, AZ., 154-160.

Gârbacea, V., Grecu, Florina, 1984, Dealurile Roandolei. Caracterizare geomorfologică, Memoriile secțiilor științifice, Academie Română, Seria IV, tom VII, Ed. Academiei, Bucureşti, pp. 235 - 242.

Grecu, Florina, Sandu, Maria, 1999, The Hârtibaciu Tableland. Geomorphological risk, Studia Geomorphologica Carpatho-Balcanica, Polonia, pag. 95- 105.

Hartel, T., Réti, Kinga-Olga, Craioveanu, Cristina, Gallé, R., Popa, R., Ioniță, Alina, Demeter, L., Rákosy, L., Czúcz, B., 2016, Rural social-ecological systems navigating institutional transitions: Case study from Transylvania (Romania), Ecosystem Health and Sustainability, 2, 1-12.

Hartel, T., Hanspach, J., Moga, C.I., Holban, L., Szapanyos, A., Tamás, Réka, Hováth, C., Réti, Kinga-Olga, 2018, Abundance of large old trees in wood pastures of Transylvania (Romania), Science of The Total Environment, 613614, 263-270.

Mitasova, Helena, Hofierka, J., Zlocha, M.L., Iverson, R., 1996, Modeling topographic potential for erosion and deposition using GIS, Journal of Geographical Information Science, 10 (5), 629-641.

Moțoc, M., Munteanu, S., Băloiu, V., Stănescu, P., Mihai, Gh., 1975, Eroziunea solului și metode de combatere, Ed. Ceres, București, 301 p.

Moțoc, M., Sevastel, M., 2002, Evaluarea factorilor care determină riscul eroziuni hidrice în suprafață, Editura Bren, Bucuresti, 60 p.

Muntean, O.-L., 2004, Impactul antropic asupra mediului înconjurător în Culoarul Târnavei Mari (sectorul Vânători-Micăsasa), Ed. Casa Cărții de Știință, Cluj-Napoca, 209 p.

Pop, Gr., 2001, Depresiunea Transilvaniei, Ed. Presa Universitară Clujeană, ClujNapoca, $274 \mathrm{p}$.

Roșian, Gh., 2011, Modele de geomorfologie funcțională ale sistemului vale-versant din Depresiunea Transilvaniei, Ed. Presa Universitară Clujeană, Cluj-Napoca, $330 \mathrm{p}$.

Toy, T. J., Foster, R.F., 1998, Guidelines for the Use of the Revised Universal Soil Loss Equation (RUSLE) Version 1.06 on Mined Lands, Construction Sites, and Reclaimed Lands, J.R. Galetovic Publishing Ed.

Wischemeier W.H., D.D. Smith, 1965, Predicting rainfall-erosion losses from cropland east of the Rocky Mountains: guide for the selection of practices for soil and water conservation, Agriculture Handbook No. 282, US Departament of Agriculture, Washington, D.C., 47 p. 